\title{
Trophic cues as possible triggers of mussel larval settlement in southeastern Brazil
}

\author{
Inês Leal ${ }^{1, *}$, Élodie Bouchard ${ }^{1}$, Augusto A.V. Flores ${ }^{2}$ and Réjean Tremblay ${ }^{1}$ \\ ${ }^{1}$ Institut des sciences de la mer, Université du Québec à Rimouski, 310 allée des Ursulines, Rimouski, Québec G5L 3A1, Canada \\ 2 Universidade de São Paulo, Centro de Biologia Marinha (CEBIMar/USP), Rod. Manoel Hipólito do Rego, km 131.5 11600-000, \\ São Sebastião, São Paulo, Brazil
}

Received 15 December 2017 / Accepted 11 July 2018

Handling Editor: Simon Morley

\begin{abstract}
Oligotrophic conditions may impose a nutritional challenge for the larval and early post-larval development of bivalves during the search for a suitable benthic habitat. Here we investigated what settlement cues might be important for mytilid populations in southeastern Brazil. Our results point to a trophic trigger mediating larval settlement that may include an effect of saturated fatty acids, probably linked to organic detritus and bacterial production deriving from terrestrial inputs. The prevalence of drifting in this population suggests it may be a strategy for individuals to delay final settlement until encountering favorable trophic environmental conditions.
\end{abstract}

Keywords: Brachidontes solisianus / Shell morphometry / Prodissoconch II / Dissoconch / Juvenile drifting

\section{Introduction}

Most marine benthic invertebrates exhibit a complex life cycle that involves a planktonic larval phase followed by a benthic juvenile and adult phase (Thorson, 1950). The duration of the planktonic phase may vary considerably, from only minutes to months (Pechenik, 1990). Throughout this time, larvae may drift away from their place of origin, covering distances from meters to hundreds of kilometers (Jablonski and Lutz, 1983; Pawlik, 1992). Larvae need to become competent, i.e. fully-developed and able to metamorphose, before reaching the benthos (Pawlik, 1992; Rodriguez et al., 1993). Frequently, the competent stage ends when larvae receive a highly specific settlement cue that indicates the presence of a suitable habitat (e.g. Satuito et al., 1997; Bishop et al., 2006; Thiyagarajan, 2010).

Larvae may respond to a series of stimuli (environmental cues) over the course of habitat selection, such as substratum texture and/or thermal capacity, presence of conspecifics, biofilms, among others (Pawlik, 1992; Rodriguez et al., 1993; Dobretsov, 1999; Thiyagarajan, 2010; Gribben et al., 2011). For example, the composition of the bacterial community of biofilms may inhibit or stimulate the attachment of benthic invertebrates (Olivier et al., 2000). For mytilid populations, biofilm-derived cues have been shown to act in a hierarchical

\footnotetext{
*Corresponding author: ines . agravasconcelosleal@uqar.ca
}

order together with planktonic ones, the last being more influential if present (Toupoint et al., 2012a). Importantly, in the absence of such cues, larvae remain adrift in the plankton before metamorphosing to adult form, i.e. delaying metamorphosis (Pechenik, 1990; Pawlik, 1992). Recently, Martel et al. (2014) reported that $M$. edulis larvae typically delay metamorphosis in natural conditions c.a. 15 days. The authors found that a small size at metamorphosis, associated with shorter larval duration, resulted in greater settlement success rates. Indeed, delaying metamorphosis may be a "doubleedged sword" due to a depletion of energetic reserves and consequent decrease in larval condition (Pechenik et al., 1993; Elkin and Marshall, 2007). Yet, for planktotrophic larvae, it may be beneficial for a short-period of time; larvae may increase their energy reserves in the presence of a patch of high food resources and therefore increase their chance of finding a suitable adult habitat (Philips, 2002).

The trophic conditions that larvae experience during their planktonic development may greatly influence juvenile performance (Pechenik et al., 1998; Philips, 2002; Emlet and Sadro, 2006; Thiyagarajan, 2010). The lipid content of pre-metamorphic larvae has been shown to be one of the factors explaining settlement success of bivalves (pectinids, Pernet et al., 2004; ostreids, Burke et al., 2008; mytilids, Rayssac et al., 2010). Toupoint et al. (2012b) found that, over consecutive years, major settlement peaks of Mytilus edulis were synchronized with phytoplanktonic pulses rich in essential fatty acids. Based on this evidence, the authors proposed the "trophic settlement trigger" 
hypothesis, suggesting a bottom-up influence of primary production and dietary lipid quality on recruitment success (Toupoint et al., 2012b). Moreover, Martel et al. (2014) suggested that the recurring metamorphosis delays observed for the same species might be caused precisely by the absence of a suitable substrate or a specific trophic cue to trigger settlement.

Even weeks after the first settlement, early mussel settlers can re-suspend in the water column through drifting (e.g. byssus, threads) or crawling, a process called secondary dispersal (Lane et al., 1985; Armonies, 1992; Shanks and Shearman, 2011; Le Corre et al., 2013). An analogous behaviour found in terrestrial systems would be the "ballooning" activity for the dispersal of many juvenile spiders (e.g. Humphrey, 1987) and in marine systems the mucous threads used for drifting by some gastropods (e.g. Martel and Chia, 1991). Le Corre and co-authors (2013) reported that secondary dispersal of Mytilus spp. greatly contributed to local recruitment dynamics, with several peaks throughout the summer in a boreal estuary. Through secondary dispersal, postlarvae may select a more suitable adult habitat, possibly far from the initial settlement site, thus increasing their distributional range (Shanks and Shearman, 2011). Despite its contribution to the population dynamics of an array of benthic invertebrates, the relative importance of post-larval drifting is not well documented in the literature and may be more common, at least for bivalves, than previously assumed (e.g., Martel and Chia, 1991; Baker and Mann, 1997; Le Corre et al., 2013).

The aim of this study was primarily to gain insights on bivalve settlement dynamics in a subtropical region, where populations of benthic invertebrates that dominate the upper shores are often subjected to low food supply conditions (Kasten and Flores, 2013; Flores et al., 2015; Kasten et al. submitted). Such conditions may impose a challenge for competent planktotrophic larvae and early post-larvae of intertidal bivalves during their search for a suitable benthic habitat, raising the question: what settlement cues might be acting in subtropical oligotrophic regions? Here, we addressed this question for mytilid populations in southeastern Brazil by (1) characterizing nearshore trophic conditions, and (2) examining shell variables of mussel post-larvae indicative of drifting. We expect that under the effects of settlement triggers, recruits will be characterized by lower post-competency growth, i.e. restricted drifting, and lower variation of shell morphometrics.

\section{Material \& methods}

Populations of the mytilid Brachidontes solisianus (Orbigny, 1846) were sampled in the southeastern coast of Brazil. B. solisuanus dominates the mid intertidal zone of the rocky shores of São Paulo State, together with chthamalid barnacles (Petersen et al., 1986; Eston et al., 1986). During February and March 2015, samplings were carried out at 7 random dates at two different sites on the São Sebastião Channel (SSC): Baleeiro Head $\left(23^{\circ} 49^{\prime} 45^{\prime \prime} \mathrm{S}, 45^{\circ} 25^{\prime} 25^{\prime \prime} \mathrm{W}\right)$, located in the enclosed CEBIMar area, and Feiticeira Beach $\left(23^{\circ} 50^{\prime} 45.76^{\prime \prime} \mathrm{S}, 45^{\circ} 24^{\prime} 34.79^{\prime \prime} \mathrm{W}\right)$, located in Ilhabela. Samples were collected at the Center for Marine Biology of the
University of São Paulo (CEBIMar/USP) and processed at the Institute of Ocean Sciences of Rimouski (ISMER/UQAR).

To characterize the trophic resources available for the seston-feeding post-larvae, three replicate samples $(2 \mathrm{~L}$ per replicate) were obtained at each sampling day and site. Samples were filtered on a $20 \mu \mathrm{m}$ mesh sieve, stored in opaque bottles and subsequently filtered on GF/F $25 \mathrm{~mm}$ Whatman filters for estimation of particulate organic matter (POM; $\mathrm{mg} \mathrm{L}^{-1}$ ), mass of total fatty acids of seston (MTFA; $\mu \mathrm{g} \mathrm{mg}^{-1}$ POM) and its composition ( $\%$ fatty acids), following the protocol described in Toupoint et al. (2012b). MTFA were further discriminated into saturated (SFA), monounsaturated (MUFA) and polyunsaturated (PUFA) fatty acids. To test the variability in trophic conditions in time (days) and space (sites separated by a few km), two-way random effects ANOVAs were run on POM and MTFA data. Because SFAs made up most of the lipid contents (see results), this fraction was further decomposed into specific fatty acids. The analogous PERMANOVA routine was run to test for temporal and spatial variations. Euclidian distances and 9,999 permutations were used to calculate pseudo- $F$ ratios. These analyses provided a measure of the consistency of seston SFA classes in the area.

To collect Brachidontes solisianus post-larvae, ten multifilament nylon scouring pads (tuffy pads) were randomly installed over a 100-m stretch along the lower midlittoral zone, where adults predominate. Tuffy pads were replaced daily at each site, and settlers extracted with a high-pressure jet of seawater into a $100 \mu \mathrm{m}$ mesh sieve. After being identified under a stereomicroscope (Monteiro-Ribas et al., 2006), individual post-larvae were preserved for morphometric analyses, which included the estimation of total shell length, and its two components: prodissoconch II (PII) length and dissoconch length $(\mu \mathrm{m})$ (following the method described in Martel et al., 1995, 2014). PII shell is secreted once the veliger can feed in the plankton and until the competent pediveliger metamorphoses into a post-larva (size at first settlement). Dissoconch shell is secreted after this first settlement, when the post-larva is crawling over the benthic habitat or re-suspended in the water column (here considered 'drifting'). The ratio between the total shell length and PII length was used as a proxy of drift and was compared between sites and among daily cohorts. A total of 246 individual post-larvae were collected and measured. Multiple linear regression analyses were carried out to identify the environmental parameter(s) (POM, SFAs, PUFAs, MUFAs) with the highest explanatory power for the observed variation of post-metamorphic drifting. Mass of total fatty acids was collinear to the mass of SFAs and was not included in the analysis. No collinearity was observed between any other pairs of the variables tested $(r<|0.70|$; Dormann et al., 2013).

\section{Results \& discussion}

Our results on the trophic status of the nearshore water column agree with previous studies indicating that the SCC is principally a meso-oligotrophic environment (Ciotti et al., 2010; Kasten and Flores, 2013; Barbosa et al., 2016), considering the relatively low POM $\left(1.02 \pm 0.03 \mathrm{mg} \mathrm{L}^{-1}\right)$ and MTFA measured over this study (MTFA; $17.68 \pm 1.06 \mu \mathrm{g} \mathrm{mg}^{-1}$ POM). Overall, organic inputs (POM) showed some spatial coherence 

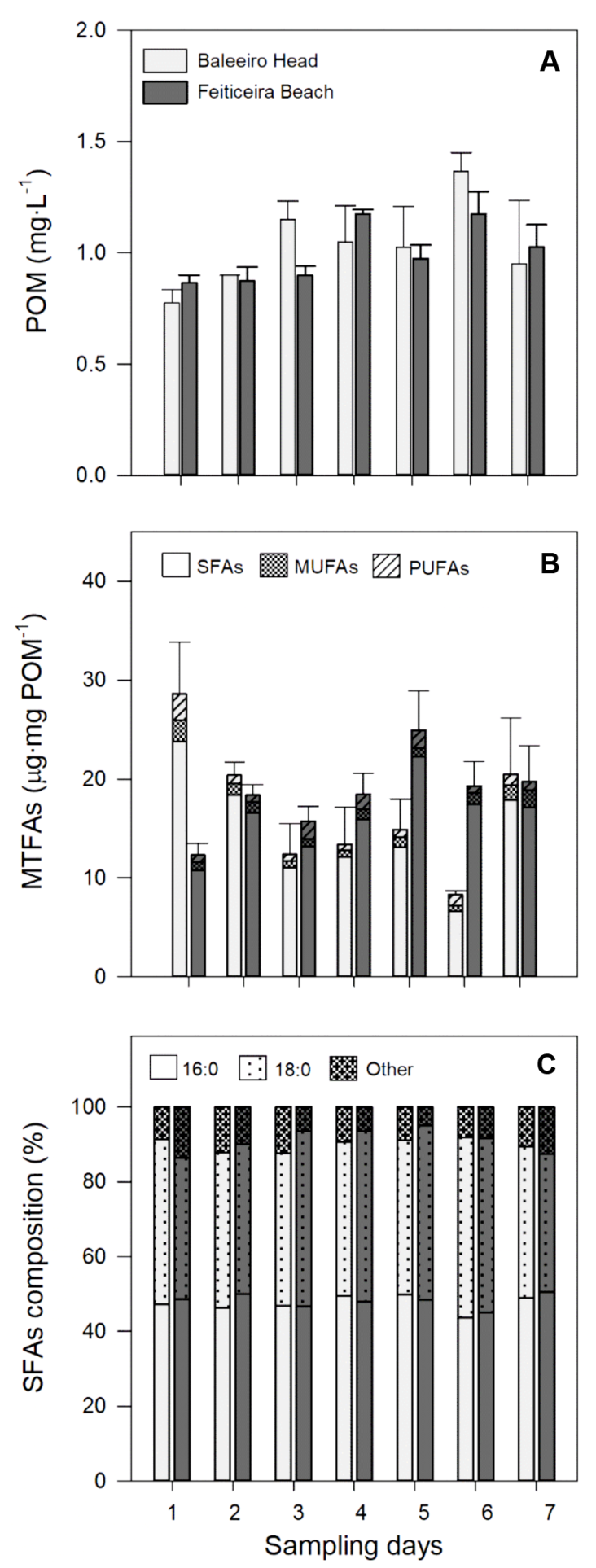

Fig. 1. Trophic conditions in the São Sebastião Channel throughout the sampling period. A) Particulate organic matter (POM); B) Mass of total fatty acids (MTFA); C) Composition of seston's saturated fatty acids (SFA). Values shown are averages and error bars are SE.

$\left(F_{\text {site }}=1.11 ; p=0.332\right)$, with similar variation at both sites across time (Fig. 1A), as suggested by the lack of interactive site $v s$. date effects $\left(F_{\text {dayXsite }}=1.00, p=0.445\right)$ in spite of significant overall temporal variation $\left(F_{\mathrm{day}}=4.50, p=0.045\right)$. However, the trophic quality of the organic inputs (as MTFAs) was markedly inconsistent across the spatial and temporal scales examined (Fig. 1B), with spatial contrasts found at some sampling dates but not in others $\left(F_{\text {dayXsite }}=4.29 ; p=0.003\right)$. Such inconsistencies are typical of the effects of scattered and short-term oceanographic processes (1-2days), leading to localized vertical mixing and relative surplus production above low baseline levels (Ciotti et al., 2010; Kasten and Flores, 2013). In other words, while the overall quantity of potential food sources varied consistently through time at sites separated by a few $\mathrm{km}$, the lipid budget, which has been shown to be critical for a number of invertebrate larvae (e.g. Phillips, 2002; Pernet et al., 2004; Rayssac et al., 2010) is far more erratic.

A more detailed assessment of nearshore seston lipids shows that, compared to most other coastal systems studied worldwide (e.g. Budge and Parrish, 1998; Toupoint et al., 2012b; Cabrol et al., 2015), the fraction of saturated fatty acids (SFAs) in the seston is stable and remarkably high $(87 \%$; $15.47 \pm 6 \mu \mathrm{g} \mathrm{mg}^{-1}$ POM) and much higher than monounsaturated fatty acids (MUFAs; $1.07 \pm 0.62 \mu \mathrm{g} \mathrm{mg}^{-1} \mathrm{POM}$ ) and polyunsaturated fatty acids (PUFAs; $1.14 \pm 0.63 \mu \mathrm{g} \mathrm{mg}^{-1}$ POM) (Fig. 1B). The high concentrations of SFAs were attributed to the high contribution of 16:0 and 18:0 fatty acids (Fig. 1C), whose joint share remained around 91\% (ranging from 82 to $96 \%$ ), with differences between sites on some dates (PERMANOVA; pseudo- $F_{\text {dayXsite }}=2.93, \quad p=0.002$ ). The amount of SFAs reported here differ considerably from those reported for temperate (40-70\%; Toupoint et al., 2012b) and subarctic systems $(\approx 30 \%$; Cabrol et al., 2015). The SFAdominated lipid composition within our study area suggests that the main food sources for benthic suspension feeders in the SCC seemed to be bacteria and detritus, unlike several temperate productive systems, in which phytoplankton blooms make the bulk of primary production (Kelly and Scheibling, 2012). We observed that fatty acid trophic markers (Parrish, 2013) of diatoms (20:5n3) and dinoflagellates (22:6n3) represented each less than $2 \%$ comparatively to the $5.9 \%$ for fatty acids specific of bacteria (15:0, 17:0, 17:1 and 16:1n7) and $6 \%$ fatty acids markers of mangroves, vascular and terrestrial plants $(18: 1 \mathrm{n} 9,18: 2 \mathrm{n} 6,18: 3 \mathrm{n} 3,24: 0)$. Because sampling took place close to the end of the rainy season, it is probable that this heterotrophic production had its origin on land. Indeed, recent studies show that seasonal changes in fluvial forcing drive terrestrial inputs of nutrients and particulate organic matter in this system (Gorman et al. in press).

Multiple regression analyses indicate that both POM and SFAs (not PUFAs or MUFAs), may possibly trigger settlement of $B$. solisianus, as assumed by the correlation of these variables with estimates of post-metamorphic drift $\left(R^{2}=0.63\right.$; $p<0.05$; Tab. 1; Fig. 2A and B). These trophic signals appear to be correlated with an early response of settlers within a narrow size range and limited post-metamorphic drift (\% CV; $R^{2}=0.65 ; p<0.001$; Fig. 2C). Based on previous studies reporting shell morphometry on different bivalve species (Martel et al., 2014), our results strongly suggest that postlarval drifting behavior is commonplace in the area. Decreasing coefficient of variation with increasing average estimates of drift (Fig. 2C) suggests that, in the presence of any positive settlement triggers, the whole larval pool in nearshore waters will respond and settle, while in the absence of such triggers only larvae that cannot further delay metamorphosis 
Table 1. Summary statistics of the multiple linear regression analyses explaining the variation of juvenile drifting according to the trophic parameters of nearshore waters (particulate organic matter: POM; saturated: SFA; monounsaturated: MUFA; and polyunsaturated fatty acids: PUFA).

\begin{tabular}{|c|c|c|c|c|}
\hline Variable & Coefficient & Std. Error & $t$ & $p$ \\
\hline POM & -1.034 & 0.391 & -2.64 & 0.027 \\
\hline SFAs & -0.058 & 0.016 & -3.60 & 0.006 \\
\hline MUFAs & 0.100 & 0.144 & 0.69 & 0.507 \\
\hline PUFAs & 0.173 & 0.088 & 1.95 & 0.082 \\
\hline R-squared $\left(\mathbf{R}^{2}\right)$ & 0.633 & $\begin{array}{l}\text { Sum of } \\
\text { Squares (SS) }\end{array}$ & 0.388 & \\
\hline Adj. R-squared & 0.470 & F-statistic & 3.878 & \\
\hline SE of regression & 0.158 & Prob(F-statistic) & 0.042 & \\
\hline
\end{tabular}

will settle. Assuming that nearshore populations of competent larvae would be comprised mostly by no- or early-drifters, settlers responding to triggers would be of very similar size. Differently, in the absence of such triggers, only long-term drifters, with remarkably different size, would respond and settle. Although there was a similar variation in shell morphometrics at both sites across time (except at Feiticeira Beach at days 1 and 3; Fig. 3), dissoconch lengths ranged from 13 up to $2,000 \mu \mathrm{m}$. The importance of trophic processes in determining settlement in the meso-oligotrophic SSC has been already suggested for barnacles (Barbosa et al., 2016), but, so far, the origin and importance of seston nutrients remains unknown. The share of SFAs in lipid profiles has been shown to be higher in marine subtropical organisms compared to temperate or polar ones (Budge and Parrish, 1998; Colombo et al., 2016). Specifically, organic detritus have been suggested to be an important energy source for mussels at times when primary production is scant (Rodhouse et al., 1984). High levels of 16:0 and 18:0 SFAs have been observed in rocky shore mytilids inhabiting environments abundant in detritic matter and bacterial load, presumably having a structural-type function (Galap et al., 1999; Freites et al., 2002). SFAs accumulation has also been shown to be important for zooplankton species (Cabrol et al., 2015). The authors suggested that accumulating SFAs may be advantageous under high energetic demands (e.g. demanding osmoregulatory processes), given their efficient oxidation and high energy yield. In oligotrophic conditions, patches of high quantity and quality of food may thus be critical for the initial growth of post-larvae. Other trophic cues have been shown to mediate settlement in other mytilids. For instance, picoplankton species involved in the diet of competent mussel larvae (pediveligers) act as a trophic settlement trigger for Mytilus edulis (Jolivet et al., 2016). Here, we propose that SFAs may play a similar role, inducing larval settlement in the subtropical mussel $B$. solisianus by signaling a favorable benthic environment on a typically nutrient-depleted region. Such cues appsear to derive from terrestrial inputs, which have been suggested to be an important energetic subsidy to the nearshore food webs in this area (Gorman et al. in press). Yet, planktonic-derived cues (i.e., phytoplanktonic exoproducts) have previously been suggested as chemical cues potentially acting in the settlement of other
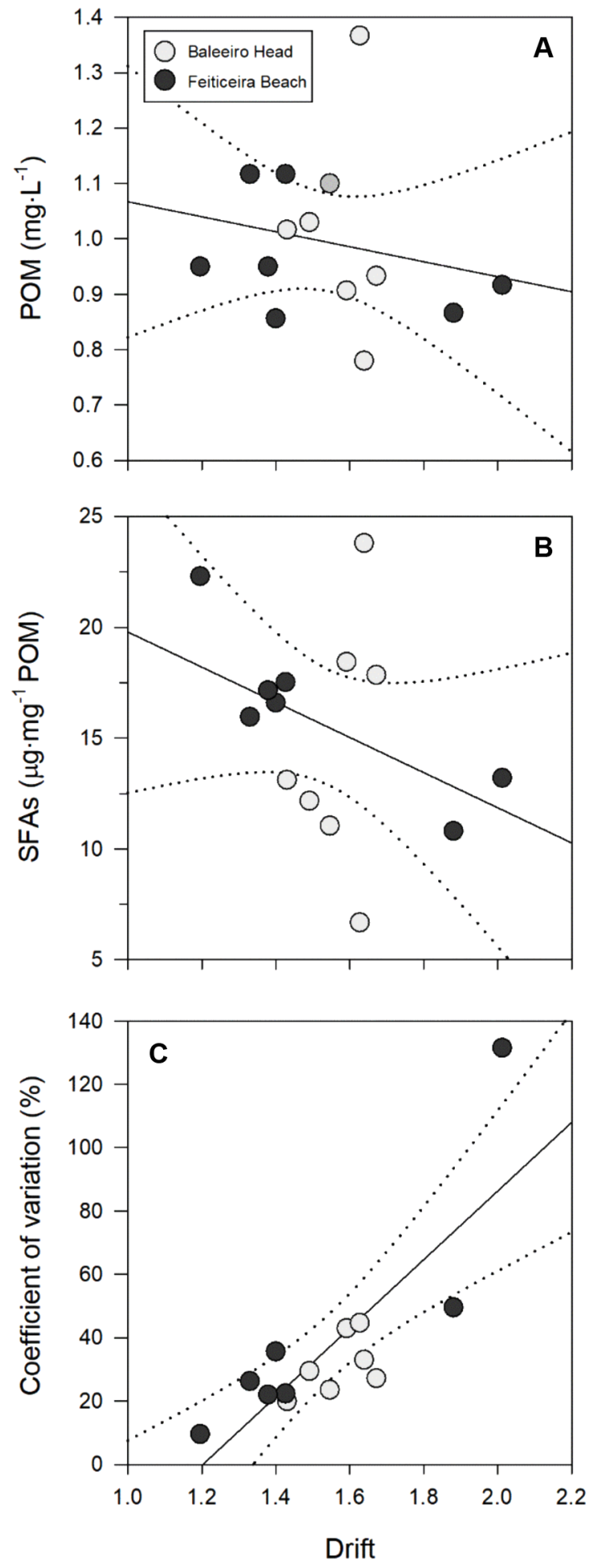

Fig. 2. ariables explaining juvenile drifting behaviour: A) Particulate organic matter (POM), B) Saturated fatty acids (SFA). Panel C depicts increasing variance with drift estimates. Dotted lines represent confidence intervals $(95 \%)$.

mytilids (Toupoint et al., 2012b). Thus, one should not overlook the multitude of cues that may influence (inducing or inhibiting) the settlement of benthic invertebrates (i.e., conspecifics, biofilm, substrate characteristics), that were 


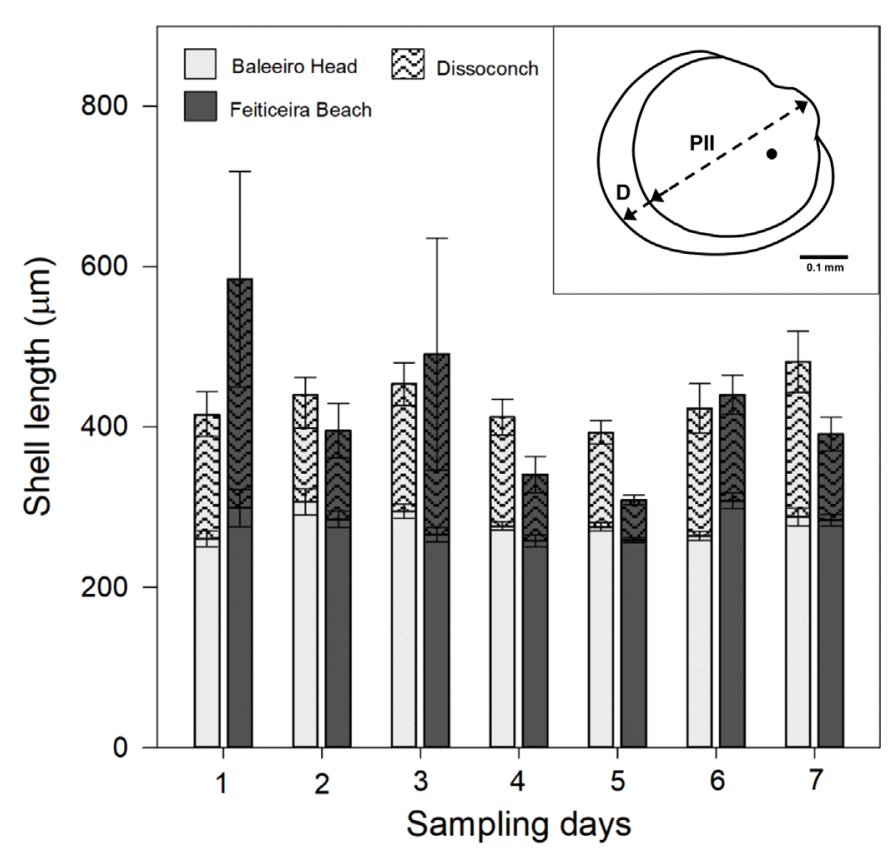

Fig. 3. Shell morphometry of Brachidontes solisianus post-larvae at Baleeiro Head and Feitieira Beach throughout the sampling period. Averages and respective SEs are shown for prodissoconch II (PII) and dissoconch (D) shells (marked in lined pattern). The indent shows the delimitation of both shells drawn from an image of a primary $B$. solisianus settler.

not investigated here. Other cues, together with planktonicderived ones (i.e., nutritional cues), may as well stimulate the settlement of $B$. solisianus in this subtropical region. This study presents preliminary evidence suggesting the importance of SFAs as a trophic trigger, but other stimuli not addressed here may be important. Future studies should consider the interplay of trophic and non-trophic signaling in the mediation of larval settlement of marine benthic invertebrates.

\section{Conclusion}

We present results that preliminary support the hypothesis of a trophic (i.e., nutritional) trigger mediating larval settlement of the subtropical mytilid $B$. solisianus. It is important to note, however, that the evidence we present here is correlational, not necessarily involving a cause-effect relationship. Such a trigger may include an effect of SFAs, commonly linked to organic detritus and bacterial production, possibly acting together with other local cues (i.e., presence of conspecifics and/or biofilm). In the absence of these cues, a considerable fraction of settlers were late post-larvae that probably remained adrift for some time (building up a shell size of up to $2 \mathrm{~mm}$, as reported). The prevalence of drifting suggests this may be a strategy for individuals to delay final settlement until encountering favorable trophic conditions, which may be particularly adaptive in meso to oligotrophic environments. From an ecological perspective, drifting may also be an alternative means of transportation, allowing for benthic species to better exploit available habitat, escape adverse conditions and potentially colonize new areas (Martel and Chia, 1991). Further work should aim longer term sampling to better assess seasonal trends of nearshore trophic conditions that may mediate juvenile drifting and settlement in this region.

Acknowledgment. We sincerely thank Nathalie Gauthier for all assistance during field work and morphometric analyses and Jean-Bruno Nadalini and Mathieu Babin for their help and expertise with lipid analyses (UQAR/ISMER). This research was funded by the Natural Sciences and Engineering Research Council of Canada (NSERC Discovery grant awarded to Réjean Tremblay).

\section{References}

Armonies W. 1992. Migratory rhythms of drifting juvenile molluscs in tidal waters of the Wadden Sea. Mar Ecol Prog Ser 197-206.

Baker P, Mann R. 1997. The postlarval phase of bivalve mollusks: a review of functional ecology and new records of postlarval drifting of Chesapeake Bay bivalves. Bull Mar Sci 61: 409-430.

Barbosa AC, Gomes CC, Pereira GC, Bueno M, Flores AAV. 2016. Local biological drivers, not remote forcing, predict settlement rate to a subsubtropical barnacle population. Mar Ecol Prog Ser 543: 201-208.

Bishop CD, Huggett MJ, Heyland A, Hodin J, Brandhorst BP. 2006. Interspecific variation in metamorphic competence in marine invertebrates: the significance for comparative investigations into the timing of metamorphosis. Integr Comp Biol 46: 662-682.

Budge SM, Parrish CC. 1998. Lipid biogeochemistry of plankton, settling matter and sediments in Trinity Bay, Newfoundland. II. Fatty acids. Org Geochem 29: 1547-1559.

Burke K, Bataller É, Miron G, Ouellette M, Tremblay R. 2008. Larval quality of a nonnative bivalve species (European oyster, Ostrea edulis) off the east Canadian coast. J Shellfish Res 27: 701-710.

Cabrol J, Winkler G, Tremblay R. 2015. Physiological condition and differential feeding behaviour in the cryptic species complex Eurytemora affinis in the St Lawrence estuary. J Plankton Res 37: 372-387.

Ciotti AM, Garcia CAE, Jorge DSF. 2010. Temporal and meridional variability of Satellite-estimates of surface chlorophyll concentration over the Brazilian continental shelf. Panam. J Aquat Sci 5: 236-253.

Colombo SM, Wacker A, Parrish CC, Kainz MJ, Arts M.T. 2016. A fundamental dichotomy in long-chain polyunsaturated fatty acid abundance between and within marine and terrestrial ecosystems. Environ Rev 999: 1-12.

Dobretsov SV. 1999. Effects of macroalgae and biofilm on settlement of blue mussel (Mytilus edulis L.) larvae. Biofouling 14: 153-165.

Dormann CF, Elith J, Bacher S, Buchmann C, Carl G, Carré G, Marquéz JRG, Gruber B, Lafourcade B, Leitão PJ, Münkemüller T. 2013. Collinearity: a review of methods to deal with it and a simulation study evaluating their performance. Ecography 36 : $27-46$.

Elkin C, Marshall DJ. 2007. Desperate larvae: influence of deferred costs and habitat requirements on habitat selection. Mar Ecol Prog Ser 335: 143-153.

Emlet RB, Sadro SS. 2006. Linking stages of life history: how larval quality translates into juvenile performance for an intertidal barnacle (Balanus glandula). Integr Comp Biol 46: 334-346.

Eston VR, Galves A, Jacobi CM, Langevin R, Tanaka NI. 1986. Chthamalus bisinuatus (Cirripedia) and Brachidontes solisianus 
(Bivalvia) spatial interactions: a stochastic model. Ecol Modell 34: 99-113.

Flores AAV, Christofoletti RA, Peres ALF, Ciotti AM, Navarrete SA. 2015. Interactive effects of grazing and environmental stress on macroalgal biomass in subsubtropical rocky shores: modulation of bottom-up inputs by wave action. J Exp Mar Biol Ecol 463: 39-48.

Freites L, Fernandez-Reiriz MJ, Labarta U. 2002. Fatty acid profiles of Mytilus galloprovincialis (Lmk) mussel of subtidal and rocky shore origin. Comp Biochem Physiol B Biochem Mol Biol 132: 453-461.

Galap C, Netchitaïlo P, Leboulenger F, Grillot JP. 1999. Variations of fatty acid contents in selected tissues of the female dog cockle (Glycymeris glycymeris L., Mollusca, Bivalvia) during the annual cycle. Comp Biochem Physiol Part A Mol Integr Physiol 122: 241-254.

Gorman D, Pucci M, Soares L, Turra A, Schlacher TA. In press Landocean connectivity through subsidies of terrestrially-derived organic matter to a nearshore marine consumer.

Gribben PE, Jeffs AG, de Nys R, Steinberg PD. 2011. Relative importance of natural cues and substrate morphology for settlement of the New Zealand Greenshell ${ }^{\mathrm{TM}}$ mussel, Perna canaliculus. Aquaculture 319: 240-246.

Humphrey JAC. 1987. Fluid mechanic constraints on spider ballooning. Oecologia 73: 469-477.

Jablonski D, Lutz RA. 1983. Larval ecology of marine benthic invertebrates: paleobiological implications. Biol Rev 58: 21-89.

Jolivet A, Tremblay R, Olivier F, Gervaise C, Sonier R, Genard B, Chauvaud L. 2016. Validation of trophic and anthropic underwater noise as settlement trigger in blue mussels. Sci Rep 6: 33829.

Kasten P, Flores AAV. 2013. Disruption of endogenous tidal rhythms of larval release linked to food supply and heat stress in an intertidal barnacle. Mar Ecol Prog Ser 472: 185-198.

Kasten P, Jenkins SR, Tremblay R, Flores AAV. Submitted. Evidence for enhanced late-stage larval quality, not survival, through maternal carry-over effects in a space monopolizing barnacle. Mar Biol

Kelly JR, Scheibling RE. 2012. Fatty acids as dietary tracers in benthic food webs. Mar Ecol Prog Ser 446: 1-22.

Lane DJW, Beaumont AR, Hunter JR. 1985. Byssus drifting and the drifting threads of the young post-larval mussel Mytilus edulis. Mar Biol 84: 301-308.

Le Corre N, Martel AL, Guichard F, Johnson LE. 2013. Variation in recruitment: differentiating the roles of primary and secondary settlement of blue mussels Mytilus spp. Mar Ecol Prog Ser 481: 133-146.

Martel A, Chia FS. 1991. Drifting and dispersal of small bivalves and gastropods with direct development. J Exp Mar Biol Ecol 150: 131-147.

Martel A, Hynes TM, Buckland-Nicks J. 1995. Prodissoconch morphology, planktonic shell growth, and size at metamorphosis in Dreissena polymorpha. Can J Zool 73: 1835-1844.

Martel AL, Tremblay R, Toupoint N, Olivier F, Myrand B. 2014. Veliger size at metamorphosis and temporal variability in prodissoconch II morphometry in the blue mussel (Mytilus edulis): Potential impact on recruitment. J Shellfish Res 33: 443-455.

Monteiro-Ribas W, Rocha-Miranda F, Romano RC, Quintanilha J. 2006. Larval development of Brachidontes solisianus (Bivalvia,
Mytilidae), with notes on differences between its hinge system and that of the mollusk Perna perna. Bras J Biol 66: 109-116.

Olivier F, Tremblay R, Bourget E, Rittschof D. 2000. Barnacle settlement: field experiments on the influence of larval supply, tidal level, biofilm quality and age on Balanus amphitrite cyprids. Mar Ecol Prog Ser 199: 185-204.

Parrish CC. 2013. Lipids in marine ecosystems. ISRN Oceanography 2013: 1-16 604045

Pawlik JR. 1992. Chemical ecology of the settlement of benthic marine invertebrates. Oceanogr Mar Biol Annu Rev 30: 273-335.

Pechenik JA. 1990. Delayed metamorphosis by larvae of benthic marine invertebrates: does it occur? Is there a price to pay? Ophelia 32: 63-94.

Pechenik JA, Rittschof D, Schmidt AR. 1993. Influence of delayed metamorphosis on survival and growth of juvenile barnacles Balanus amphitrite. Mar Biol 115: 287-294.

Pechenik JA, Wendt DE, Jarrett JN. 1998. Metamorphosis is not a new beginning. BioScience 48: 901-910.

Pernet F, Tremblay R, Langdon C, Bourget E. 2004. Effect of additions of dietary triacylglycerol microspheres on growth, survival, and settlement of mussel (Mytilus sp.) larvae. Mar Biol 144: 693-703.

Petersen JA, Sutherland JP, Ortega S. 1986. Patch dynamics of mussel beds near São Sebastião (São Paulo), Brazil. Mar Biol 93: 389_ 393.

Phillips NE. 2002. Effects of nutrition-mediated larval condition on juvenile performance in a marine mussel. Ecology 83: 2562-2574.

Rayssac N, Pernet F, Lacasse O, Tremblay R. 2010. Temperature effect on survival, growth, and triacylglycerol content during the early ontogeny of Mytilus edulis and M. trossulus. Mar Ecol Prog Ser 417: 183-191.

Rodhouse PG, Roden CM, Burnell GM, Hensey MP, McMahon T, Ottway B, Ryan TH. 1984. Food resource, gametogenesis and growth of Mytilus edulis on the shore and in suspended culture: Killary Harbour, Ireland. J Mar Biolog Assoc UK 64: 513-529.

Rodriguez SR, Ojeda FP, Inestrosa NC. 1993. Settlement of benthic marine invertebrates. Mar Ecol Prog Ser 193-207.

Satuito CG, Shimizu K, Fusetani N. Studies on the factors influencing larval settlement in Balanus amphitrite and Mytilus galloprovincialis. in: Live Food in Aquaculture. Springer Netherlands 1997, pp. $275-280$

Shanks AL, Shearman RK. 2011. Thread-drifting juvenile Mytilus spp. in continental shelf waters off Coos Bay, Oregon, USA. Mar Ecol Prog Ser 427: 105-115.

Thiyagarajan V. 2010. A review on the role of chemical cues in habitat selection by barnacles: new insights from larval proteomics. $J$ Exp Mar Biol Ecol 392: 22-36.

Thorson G. 1950. Reproductive and larval ecology of marine bottom invertebrates. Biol Rev 25: 1-45.

Toupoint N, Mohit V, Linossier I, Bourgougnon N, Myrand B, Olivier F, Lovejoy C, Tremblay R. 2012a. Effect of biofilm age on settlement of Mytilus edulis. Biofouling 28: 985-1001.

Toupoint N, Gilmore-Solomon L, Bourque F, Myrand B, Pernet F, Olivier F, Tremblay R. 2012b. Match/mismatch between the Mytilus edulis larval supply and seston quality: effect on recruitment. Ecology 93: 1922-1934.

Cite this article as: Leal I, Bouchard É, Flores AAV, Tremblay R. 2018. Trophic cues as possible triggers of mussel larval settlement in southeastern Brazil. Aquat. Living Resour. 31: 26 